\title{
PENGARUH MOTIVASI KERJA DAN KEPEMIMPINAN TERHADAP KINERJA KARYAWAN
}

\author{
Mudjiran (mudjiran65@gmail.com) \\ Siti Noor Hidayati (datik_ng@yahoo.com) \\ Fakultas Ekonomi Universitas Proklamasi 45
}

\begin{abstract}
Performance is the work result of the employees to achieve of some company goals.The purpose of this researches is to determine the effect of leadership and work motivation to the employee performance as partial and simultaneous at the UPT Pasar I Kabupaten Sleman. Research using multiple regression analysis. The result showed leadership and work motivation a significant positive effect on employee performance. It was also concluded thatleadership variable dominanly influenced on employee performance compared to work motivation.
\end{abstract}

Keyword: leadership, work motivation, employee performance

\section{PENDAHULUAN}

Sumber daya manusia (SDM) merupakan faktor utama dalam suatu organisasi. Dalam mencapai tujuannya, suatu organisasi memerlukan sumber daya manusia sebagai pengelola sistem. Agar sistem ini berjalan tentu dalam pengelolaannya harus memperhatikan beberapa aspek penting seperti kepemimpinan, motivasi, lingkungan kerja, kinerja dan aspek-aspek lainnya. Hal ini akan menjadikan manajemen sumber daya manusia sebagai salah satu indikator penting pencapaian tujuan organisasi secara efektif dan efisien. Kinerja merupakan jawaban dari berhasil atau tidaknya tujuan organisasi yang telah ditetapkan, dapat ditingkatkan dengan memberikan contoh yang baik dari seorang pemimpin. Karyawan/pegawai/pekerja/buruh adalah makhluk sosial yang menjadi kekayaan utama bagi setiap organisasi. Pekerja/buruh adalah setiap orang yang bekerja dengan menerima upah atau imbalan dalam bentuk lain (UU RI No.13 Tahun 2003 tentang ketenagakerjaan). Pegawai/Karyawan menjadi pelaku yang menunjang tercapainya tujuan organisasi, mempunyai pikiran, perasaan dan keinginan yang dapat mempengaruhi sikap-sikapnya terhadap pekerjaan. Karyawan adalah orang penjual jasa (pikiran dan tenaga) dan dapat kompensasi yang besarnya telah ditetapkan terlebih dahulu (Malayu SP Hasibuan, 2012). Keberhasilan suatu perusahaan sangat dipengaruhi oleh kinerja individu karyawan, setiap perusahaan akan selalu berusaha untuk mendapatkan kinerja terbaik dari karyawan, dengan harapan apa yang menjadi tujuan perusahaan akan tercapai.

Bagi setiap organisasi, melakukan penilaian terhadap kinerja karyawan merupakan sesuatu hal yang penting untuk mengetahui sampai seberapa jauh tujuan organisasi itu sudah berhasil diwujudkan dalam kurun waktu atau periode tertentu. Informasi tentang kinerja tersebut akan sangat bermanfaat untuk menilai dan mengevaluasi kinerja organisasi, apakah sudah sesuai dengan tujuan yang diharapkan dan juga tentang proses kerjanya, apakah sudah berjalan baik atau masih perlu diperbaiki artinya penilaian kinerja dapat dipakai sebagai ukuran keberhasilan organisasi dan dijadikan input bagi perbaikan atau peningkatan kinerja organisasi selanjutnya Cash dan Fischer (dalam Thoyib, 2005) mengemukakan bahwa kinerja sering disebut dengan performance atau result yang diartikan dengan apa yang telah dihasilkan oleh individu karyawan.. 
Menurut Anwar Prabu Mangkunegara (2005), pengertian kinerja (prestasi kerja) adalah hasil kerja secara kualitas dan kuantitas yang dicapai oleh seorang pegawai dalam melaksanakan tugasnya sesuai dengan tanggung jawab yang diberikan kepadanya Menurut Rivai (2005) Kinerja merupakan perilaku yang nyata yang ditampilkan setiap orang sebagai prestasi kerja yang dihasilkan oleh pegawai sesuai dengan perannya dalam perusahaan. Sedangkan menurut Robins ( 2006) kinerja karyawan merupakan sebuah fungsi interaksi kemampuan, motivasi dan peluang untuk bekerja. Dan menurut Hasibuan (2012), kinerja adalah merupakan suatu hasil kerja yang dicapai seseorang dalam melaksanakan tugastugasnya atas kecakapan, usaha dan kesempatan. Berdasarkan paparan di atas kinerja adalah suatu hasil yang dicapai seseorang dalam melaksanakan tugas-tugas yang didasarkan atas kecakapan, pengalaman dan kesungguhan serta waktu menurut standar dan kriteria yang telah ditetapkan sebelumnya. Menurut As'sad (2003) variabel kinerja karyawan ini secara operasional diukur dengan 3 (tiga) faktor utama yang berpengaruh pada kinerja yaitu individu (kemampuan bekerja), usaha kerja (keinginan untuk bekerja), dan dukungan organisasional (kesempatan untuk bekerja).

Untuk mengembangkan dan memberdayakan sumber daya manusia diperlukan motivasi kerja. Seperti yang dikemukakan oleh Robbin (2006) mengemukakan bahwa motivasi adalah keinginan untuk melakukan sebagai kesediaan untuk mengeluarkan tingkat upaya yang tinggi untuk tujuan-tujuan organisasi, yang dikondisikan oleh kemampuan upaya itu untuk memenuhi suatu kebutuhan individual. Motivasi menurut Mulyasa (2003) adalah tenaga pendorong atau penarik yang menyebabkan adanya tingkah laku ke arah suatu tujuan tertentu. Menurut Nawawi (2006) Motivasi merupakan "dorongan atau kehendak yang menyebabkan seseorang berbuat sesuatu". Perilaku seseorang itu hakikatnya ditentukan oleh keinginannya untuk mencapai beberap tujuan. Keinginan itu istilah lainnya ialah motivasi.

Mangkunegara (2005) menyatakan: "motivasi terbentuk dari sikap (attitude) karyawan dalam menghadapi situasi kerja di perusahaan (situation). Motivasi merupakan kondisi atau energi yang menggerakkan diri karyawan yang terarah atau tertuju untuk mencapai tujuan organisasi perusahaan. Sikap mental karyawan yang pro dan positif terhadap situasi kerja itulah yang memperkuat motivasi kerjanya untuk mencapai kinerja maksimal. Motivasi kerja adalah kondisi yang berpengaruh membangkitkan, mengarahkan dan memelihara perilaku yang berhubungan dengan lingkungan kerja (McCormic dalam Mangkunegara, 2005). Variabel motivasi kerja ini secara operasional diukur dengan menggunakan 3 (tiga) indikator, yaitu: kebutuhan berprestasi, kebutuhan fisik, dan kebutuhan rasa aman. Menurut Hasibuan (2012) Motivasi menjadi pendorong seseorang melaksanakan suatu kegiatan guna mendapatkan hasil yang terbaik. Karyawan yang mempunyai motivasi kerja yang tinggi akan mempunyai kinerja yang tinggi pula.

Pemimpin dapat mempengaruhi moral, kepuasan kerja, keamanan, kualitas kehidupan kerja dan terutama tingkat prestasi suatu organisasi. Kemampuan dan ketrampilan kepemimpinan dalam pengarahan adalah faktor penting efektivitas manajer. Bila organisasi dapat mengidentifikasikan kualitas - kualitas yang berhubungan dengan kepemimpinan, kemampuan untuk menyeleksi pemimpin-pemimpin yang efektif akan meningkat, bila organisasi dapat mengidentifikasikan perilaku dan teknik - teknik kepemimpinan efektif organisasi, berbagai perilaku dan teknik tersebut akan dapat dipelajari. Yasin (2001) mengemukakan bahwa keberhasilan kegiatan usaha pengembangan organisasi, sebagian besar ditentukan oleh kualitas kepemimpinan atau pengelolanya dan komitmen pimpinan puncak organisasi untuk investasi energi yang diperlukan maupun usaha - usaha pribadi pimpinan Suranta (2002) mengatakan bahwa gaya kepemimpinan merupakan norma perilaku yang digunakan oleh seseorang pada saat orang tersebut mencoba mempengaruhi perilaku orang lain. 
Hasibuan (2012) menyatakan kepemimpinan adalah seorang yang mempergunakan tugas dan wewenangnya, yang diarahkan kepada bawahannya untuk mengerjakan pekerjaan dalam mencapai tujuan organisasi. Kepemimpinan adalah seorang pribadi yang memiliki superioritas tertentu, sehingga ia memiliki kewajiban dan kekuasaan untuk menggerakkan orang lain melakukan usaha bersama guna mencapai suatu tujuan tertentu. Proses kepemimpinan melibatkan keinginan dan niat, keterlibatan yang aktif antara pemimpin dan bawahan untuk mencapai tujuan yang diinginkan bersama. Kepemimpinan adalah proses memengaruhi orang lain kearah tujuan organisasi (Bartol dalam Tika, 2006). Variabel kepemimpinan ini secara operasional diukur dengan menggunakan 4 (empat) indikator yang diadopsi dari teori kepemimpinan situasional Hersey-Blanchard dalam Robbins (2006) yaitu: kemampuan untuk memberitahu anggota apa yang harus mereka kerjakan, kemampuan menjual/memberikan ide-ide kepada anggota, kemampuan berpartisipasi dengan anggota, dan kemampuan mendelegasikan kepada anggota.

Dengan demikian permasalahannya adalah: Bagaimana karakteristik responden (karyawan) di UPT Pasar I Kabupaten Sleman, yang meliputi jenis kelamin, usia, pendidikan dan masa kerja. Seberapa besar tingkat kinerja, motivasi kerja dan kepemimpinan pegawai di UPT Pasar I Kabupaten Sleman?. Apakah variabel motivasi kerja dan kepemimpinan berpengaruh terhadap kinerja pegawai di UPT Pasar I Kabupaten Sleman ? Dan variabel mana yang lebih dominan pengaruhnya antara motivasi kerja dan kepemimpinan terhadap kinerja pegawai UPT Pasar I Kabupaten Sleman?

Tujuan dalam penelitian ini adalah untuk menganalisis pegawai di UPT Pasar I Kabupaten Sleman meliputi

1. Karakteristik responden (pegawai) yaitu jenis kelamin, usia, pendidikan dan masa kerja.

2. Tingkat kinerja, motivasi kerja dan kepemimpinan

3. Pengaruh variabel motivasi kerja dan kepemimpinan terhadap kinerja pegawai, secara parsiil maupun secara bersama-sama..

4. Variabel yang lebih dominan pengaruhnya antara motivasi kerja dan kepemimpinan terhadap kinerja karyawan

Berdasar uraian di depan dapat dijelaskan kerangka pikir dalam penelitan ini sebagai berikut: Menurut Hasibuan (2012) Motivasi menjadi pendorong seseorang melaksanakan suatu kegiatan guna mendapatkan hasil yang terbaik. Karyawan yang mempunyai motivasi kerja yang tinggi akan mempunyai kinerja yang tinggi pula. Motivasi kerja adalah kondisi yang berpengaruh membangkitkan, mengarahkan dan memelihara perilaku yang berhubungan dengan lingkungan kerja (McCormic dalam Mangkunegara,2005). Variabel motivasi kerja ini secara operasional diukur dengan menggunakan 3 (tiga) indikator, yaitu : kebutuhan berprestasi, kebutuhan fisik, dan kebutuhan rasa aman.

Kepemimpinan adalah proses memengaruhi orang lain kearah tujuan organisasi (Bartol dalam Tika, 2006). Variabel kepemimpinan ini secara operasional diukur dengan menggunakan 4 (empat) indikator yang diadopsi dari teori kepemimpinan situasional HerseyBlanchard dalam Robbins (2006) yaitu: kemampuan untuk memberitahu anggota apa yang harus mereka kerjakan, kemampuan menjual/memberikan ide-ide kepada anggota, kemampuan berpartisipasi dengan anggota, dan kemampuan mendelegasikan kepada anggota.

Kinerja adalah merupakan hasil kerja yang secara kualitas dan kuantitas dapat dicapai oleh seorang pegawai dalam melaksanakan tugas sesuai tanggung jawab yang diberikan kepadanya (Mangkunegara, 2005). Menurut As'sad (2003) variabel kinerja karyawan ini secara operasional diukur dengan 3 (tiga) faktor utama yang berpengaruh pada kinerja yaitu individu (kemampuan bekerja), usaha kerja (keinginan untuk bekerja), dan dukungan organisasional (kesempatan untuk bekerja). 
Kerangka pikir tersebut dapat digambarkan sebagai berikut:

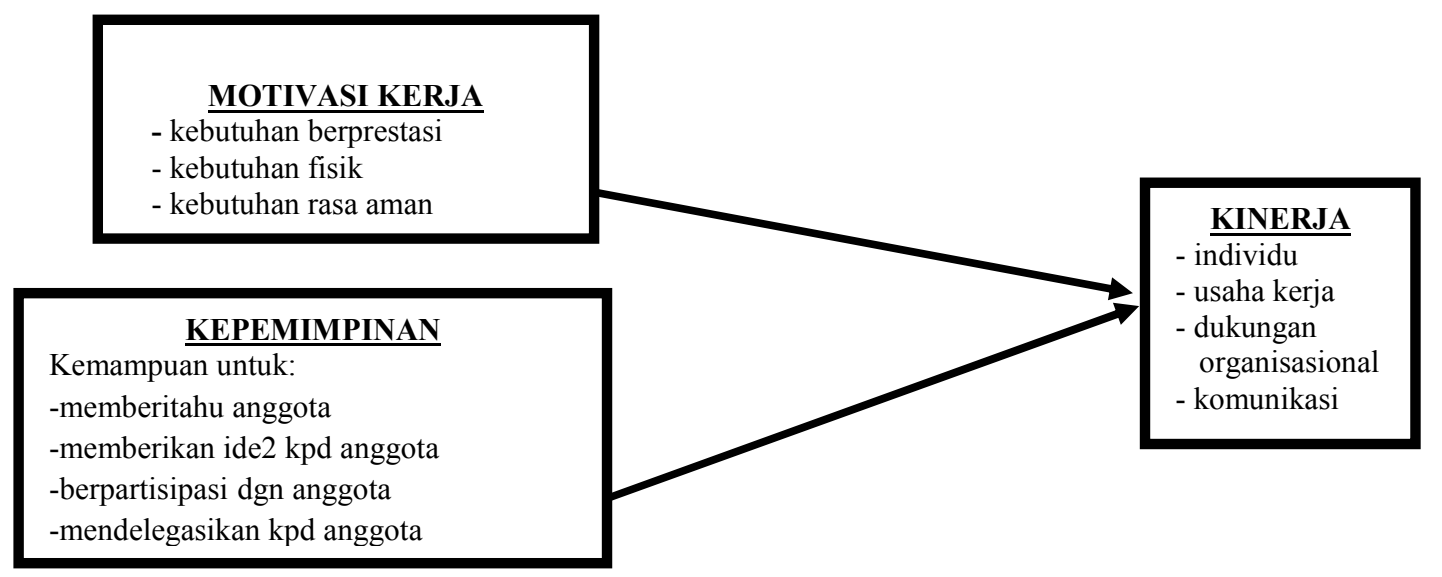

GAMBAR 1: Kerangka Pikir Penelitian

Berkenaan dengan kerangka pikir tersebut maka hipotesis yang dikemukakan di sini adalah: "Ada pengaruh Motivasi Kerja dan Kepemimpinan terhadap Kinerja Karyawan secara parsiil maupun secara bersama-sama"

\section{METODE PENELITIAN}

Penelitian dilakukan di UPT Pasar I Kabupaten Sleman ? Populasi dalam penelitian ini adalah semua yang berjumlah 22 orang. Semua populasi dijadikan responden disebut metode sensus (Sugiyono, 2010). Variabel dalam penelitian ini:

Variabel bebas (independent variable) adalah motivasi kerja dan kepemimpinan. Sedang variabel tergantug (dependent variable) adalah kinerja pegawai.

Data yang diperlukan dalam penelitian ini adalah data primer dari responden dan data sekunder dari buku-buku, majalah, koran maupun instansi yang ada kaitannya dengan penelitian. Metode pengumpulan data primer digunakan "Metode Angket", sedang metode pengukurannya dengan skala Likert yaitu skala yang digunakan untuk mengukur sikap, pendapat, persepsi dari seseorang tentang fenomena sosial (Sugiyono, 2010). Jawaban dari setiap item pernyataan disediakan 5(lima) alternatif jawaban dan penilaian untuk masingmasing alternatif jawaban diberi bobot (skor): a). Sangat Tidak Setuju (STS) skor:1, b). Tidak Setuju (TS) skor 2, c). Netral (N) skor 3, d). Setuju (S) skor 4 dan e). Sangat Setuju (SS) skor 5.

Indikator yang digunakan dalam masing-masing variabel adalah:

Variabel motivasi kerja, secara operasional diukur dengan menggunakan 3 (tiga) indikator, yaitu: kebutuhan berprestasi, kebutuhan fisik dan kebutuhan rasa aman.Variabel kepemimpinan ini secara operasional diukur dengan menggunakan 4 (empat) indikator yaitu kemampuan untuk memberitahu anggota/karyawan apa yang harus mereka kerjakan, kemampuan menjual/ memberikan ide-ide kepada anggota/karyawan, kemampuan berpartisipasi dengan anggota/ karyawan, dan kemampuan mendelegasikan kepada anggota/karyawan. Variabel kinerja karyawan ini secara operasional diukur dengan 3 (tiga) faktor utama yang berpengaruh menurut As'sad pada kinerja yaitu individu (kemampuan bekerja), usaha kerja (keinginan untuk bekerja), dan dukungan organisasional (kesempatan untuk bekerja). Masing-masing variabel dengan 5 (lima) item pertanyaan.

Uji validitas dan uji reliabilitas telah dilakukan terhadap semua angket (pernyataan) dari 3 (tiga) variabel tersebut. Uji validitas dengan menghitung korelasi Pearson Product Momen (ryx). Hasil perhitungan semua item pernyataan pada masing-masing variabel diperoleh nilai ryx-hitung lebih besar dibanding r-hitung $(0,361)$ sehingga semua dinyatakan valid). Uji 
reliabilitas dengan menghitung alpha Cronbach, hasilnya nilai alpha ketiga variabel Motivasi Kerja, Kepemimpinan dan Kinerja Karyawan di atas 0,6 sehingga semua variabel dinyatakan reliabel.

Metode analisis data yang digunakan dalam penelitian ini adalah analisis kualitatif dan analisis kuantitatif sebagai berikut:

1. Untuk menganalisis karakteristik responden (karyawan) digunakan analisis kualitatif yaitu analisis yang hanya menggunakan paparan sederhana, baik menggunakan jumlah data maupun persentase dengan membuat distribusi frekuensi (Suharsimi Arikunto, 2006).

2. Untuk menganalisis tanggapan responden (karyawan) terhadap masing-masing variabel motivasi kerja, kepemimpinan dan kinerjan karyawan digunakan Distribusi Frekuensi dan Rata-rata Hitung (Mean) . dengan interval 0,8 dan ada 5 kriteria yaitu sangat rendah, rendah, cukup, tinggi, sangat tinggi.

3. Untuk menganalisis pengaruh Motivasi kerja (X1) dan Kepemimpinam (X2) terhadap Kinerja Karyawan digunakan analisis regresi berganda (Imam Ghozali, 2008). Model persamaan regresi berganda sebagai berikut:

$$
Y=\beta_{1} X_{1}+\beta_{2} X_{2}+\varepsilon 1
$$

Untuk menguji pengaruh Motivasi Kerja dan Kepemimpinan terhadap Kinerja Karyawan secara parsiil digunakan uji t sedang uji secara bersama-sana digunakan uji $\mathrm{F}$

4).Untuk mengetahui variabel $(X)$ mana yang pengaruhnya paling dominan terhadap variabel kinerja karyawan (Y) dapat dilihat dari koefisien determinasi parsial terbesar

\section{HASIL PENELITIAN DAN PEMBAHASAN}

Pengumpulan data dengan angket dilakukan terhadap 22 responden atau semua karyawan di UPT Pasar I Kabupaten Sleman. Setelah dianalisis diperoleh hasil sebagai berikut:

1. Responden/Karyawan terbanyak adalah: jenis kelamin laki-laki yaitu 21 orang (96\%), usia di atas 40 tahun yaitu 15 orang $(68,2 \%)$ dan berpendidikan S1 yaitu 55 orang $(78,57 \%)$, dan masa kerja di atas 6 tahun yaitu 19 orang $(38,57 \%)$.

2. Tanggapan responden terhadap implementasi Motivasi kerja, Kepemimpinan dan Kinerja karyawan sebagai berikut:

a. Motivasi kerja. Dari 5 item pernyataan, sebagian besar karyawan( 15 orang atau $68,18 \%$ ) rata-rata menyatakan "sangat setuju (SS)" bahwa karyawan di UPT Pasar I Kabupaten Sleman mempunyai motivasi kerja untuk kebutuhan berprestasi, kebutuhan fisik, dan kebutuhan rasa aman dengan nilai rata-rata skor (mean) sebesar 4,36 (sangat tinggi) berarti implementasi motivasi kerjanya "sangat baik".

b. Kepemimpinan. Dari 5 item pernyataan, sebagian besar karyawan (15 orang atau 68,18\%) rata-rata menyatakan "sangat setuju (SS)" bahwa kepemimpinan di UPT Pasar I Kabupaten Sleman mempunyai kemampuan untuk memberitahu karyawan, memberikan ide-ide kepada karyawan, berpartisipasi dengan karyawan dan mendelegasikan kepada karyawan. Dengan nilai rata-rata skor (mean) sebesar 4,30 (sangat tinggi) berarti implementasi kepemimpinan "sangat baik"

c. Kinerja Pegawai. Dari 5 item pernyataan, sebagian besar karyawan rata-rata menyatakan "setuju (S)" bahwa karyawan di UPT Pasar I Kabupaten Sleman mempunyai kinerja dalam menyelesaikan pekerjaan-pekerjaan yang menjadi tanggung jawabnya yang dipengaruhi oleh individu (kemampuan bekerja), usaha kerja (keinginan untuk bekerja), dan dukungan organisasional (kesempatan untuk bekerja) dengan nilai rata-rata skor (mean) sebesar 4,16 (tinggi) berarti implementasi kinerja " baik". 
3. Berdasar hasil analisis dengan program SPSS (Singgih Santosa, 2009) diperoleh hasil sebagai berikut:

a. Sebelum dilakukan analisis regresi berganda telah dilakukan uji asumsi dasar dan asumsi klasik. Uji asumsi dasar meliputi uji linearitas dan uji normalitas. Uji linearitas untuk hubungan variabel motivasi kerja dengan kinerja dan disiplin kerja dengan kinerja, hasilnya dinyatakan signifikan atau ada hubungan linier. Dan hasil uji normalitas menunjukkan bahwa semua variabel yang digunakan dalam penelitian ini memiliki random data yang berdistribusi normal. Sedang untuk uji asumsi klasik karena datanya bersifat "cross section" maka hanya meliputi uji heteroskedastisitas yang kesimpulannya tidak terjadi heteroskedastisitas dan uji multikolinearitas yang kesimpulannya model regresi tidak terjadi masalah mutikolinearitas atau tidak terjadi korelasi di antara variabel-variabel bebas. Dengan demikian analisis regresi berganda telah memenuhi persyaratan untuk dilanjutkan.

Hasil perhitungan analisis regresi berganda dengan SPSS sebagai berikut :

Tabel 1. Rekapitulasi Hasil Perhitungan Analisis Regresi Berganda Dengan Program SPSS

\begin{tabular}{|c|c|c|c|c|c|c|}
\hline \multirow[b]{2}{*}{ Model } & Unstandardized & Coefficients & $\begin{array}{l}\text { Standardized } \\
\text { Coefficients }\end{array}$ & \multirow[b]{2}{*}{$\mathrm{t}$} & \multirow[b]{2}{*}{ Sig. } & \multirow{2}{*}{$\frac{\text { Correlation }}{\text { Partial }}$} \\
\hline & $\mathrm{B}$ & Std Error & Beta & & & \\
\hline (Constant) & 4,723 & ,2,616 & & 2,598 &, 087 & \\
\hline Motivasi Kerja $\mathrm{X}_{1}$ & 279 & , 138 & ,297 & 2,022 & 031 & ,211 \\
\hline Kepemimpinan $\mathrm{X}_{2}$ &, 322 & ,116 & ,434 & 4,115 &, 012 & ,537 \\
\hline Model & Sum of Squares & Df & $\begin{array}{l}\text { Mean } \\
\text { Square }\end{array}$ & $\overline{\mathrm{I}}$ & & Sig \\
\hline Regression & 7,344 & 2 & 3,672 & & 5,075 & ,017 \\
\hline Residual & 13,747 & 19 &, 724 & & & \\
\hline Total & 21,091 & 21 & & & & \\
\hline
\end{tabular}

Dependent Variable: Kinerja Y

Sumber: olah data dengan SPSS, 2013

b. Persamaan regresi berganda: $\quad \mathrm{Y}=4,723+0,276 \mathrm{X}_{1}+0,322 \mathrm{X}_{2}$

$\mathrm{Y}=$ variabel kinerja $; \quad \mathrm{X}_{1}=$ variabel motivasi kerja; $\quad \mathrm{X}_{2}=$ variabel kepemimpinan

Semua koefisien regresi untuk semua variabel bertanda positip, hal ini menggambarkan bahwa jika motivasi kerja dan kepemimpinan di tingkatkan maka kinerja karyawan juga akan meningkat. Jika Motivasi kerja dinaikkan 1 tingkat maka kinerja karyawan akan naik 0,279 tingkat, dan jika kepemimpinan dinaikkan 1 tingkat maka kinerja karyawan akan naik 0,322 tingkat.

Hasil uji hipotesis terhadap koefisien regresi secara bersama-sama (Uji-F) diperoleh nilai F-hitung $=5,075$ dengan tingkat signifikansi (nilai probabilitas) $=0,017$ dan posisinya di bawah nilai 0,05 . Dengan demikian terbukti bahwa variabel motivasi kerja dan kepemimpinan secara bersama-sama dapat meningkatkan kinerja karyawan secara signifikan. Hal ini didukung juga dengan nilai koefisien korelasi berganda $\mathrm{R}=0,590$ (di atas 0,5 ) yang berarti korelasinya cukup kuat. Nilai koefisien determinasi berganda $\mathrm{R}^{2}=0,348=34,8 \%$ yang berarti kontribusi variabel motivasi kerja dan kepemimpinan terhadap kinerja hanya 34,8\% atau peningkatan kinerja karyawan sebanyak 34,8\% disebabkan oleh peningkatan variabel motivasi kerja dan kepemimpinan secara bersama-sama, sedang sisanya yang $65,2 \%$ disebabkan oleh hal-hal di luar variabelvariabel tersebut yang tidak masuk dalam penelitian ini.

Hasil uji hipotesis terhadap koefisien regresi secara parsial (Uji-t) diperoleh nilai thitung variabel motivasi kerja $=2,022$ dengan tingkat signifikansi (nilai probabilitas) = 
0,031; nilai t-hitung variabel kepemimpinan $=2,777$ dengan tingkat signifikansi (nilai probabilitas $)=0,012$. Nilai probabilitas semua variabel posisinya berada di bawah nilai 0,05. Dengan demikian terbukti bahwa variabel motivasi kerja dan kepemimpinan secara parsial dapat meningkatkan kinerja pegawai secara signifikan.

4. Nilai koefisien determinasi parsial ( $\left.r^{2}\right)$ variabel kepemimpinan $=(0,537)^{2}=0,288$ lebih besar dibanding $r^{2}$ variabel motivasi kerja $=(0,211)^{2}=0,045$ Dengan demikian variabel kepemimpinan pengaruhnya untuk meningkatkan kinerja kasryawan lebih dominan dari pada variabel motivasi kerja

\section{KESIMPULAN DAN SARAN}

Dari hasil penelitian dan pembahasan dapat disimpulkan:

1. Responden/Karyawan terbanyak adalah: jenis kelamin laki-laki yaitu 21 orang (96\%), usia di atas 40 tahun yaitu 15 orang $(68,2 \%)$ dan berpendidikan S1 yaitu 55 orang $(78,57 \%)$, dan masa kerja di atas 6 tahun yaitu 19 orang $(38,57 \%)$.

2. Tanggapan responden terhadap implementasi motivasi kerja: sa ngat baik (skor 4,36), kepemimpinan: sangat baik (skor 4,30) dan kinerja pegawai: baik (skor 4,16).

3. Terbukti ada pengaruh positif dan signifikan dari motivasi kerja $\left(\mathrm{X}_{1}\right)$ dan kepemimpinan $\left(\mathrm{X}_{2}\right)$ terhadap kinerja pegawai $(\mathrm{Y})$, secara parsial maupun bersama-sama. Namun kontribusi variabel motivasi kerja dan kepemimpinan terhadap kinerja karyawan $\left(\mathrm{R}^{2}\right)$ hanya $34,8 \%$.

4. Kepemuimpinan $\left(\mathrm{X}_{2}\right)$ pengaruhnya terhadap kinerja pegawai lebih dominan dibanding motivasi kerja $\left(\mathrm{X}_{1}\right)$.

Saran yang diajukan adalah dalam upaya meningkatkan kinerja karyawan guna mencapai tujuan organisasi, sebaiknya organisasi lebih memperhatikan kepemimpinan tanpa meninggalkan motivasi kerja. Selain itu sebaiknya juga dilakukan penelitian lebih lanjut dengan mengembangkan variabel-variabel penelitian di luar motivasi kerja dankepemimpinan yg koefisien determinasi bergandanya $\left(\mathrm{R}^{2}\right)$ hanya $34,8 \%$. dengan demikian diharapkan bisa lebih banyak lagi kebijakan-kebijakan yang diambil organisasi guna meningkatkan kinerja pegawai sehingga apa yang menjadi tujuan dari organisasi bisa tercsapai.

\section{DAFTAR PUSTAKA}

Arikunto, Suharsimi. 2010. Prosedur Penelitian Suatu Pendekatan Praktek. Jakarta : Rineka Cipta.

Dubrin Andrew J. 2005. Leadership (Terjemahan). Edisi Kedua. Jakarta: Prenada Media.

Ghazali, Imam. 2008. Aplikasi Analisis Multivariate dengan Program SPSS. Semarang : Badan Penerbit Universitas Diponegoro Semarang.

Malayu SP Hasibuan. 2012. Manajemen Sumber Daya Manuasia. Bumi Aksara. Jakarta.

Mangkunegara Anwar Prabu, 2005. Manajemen Sumber Daya Manusia Perusahaan, Cetakan Keenam, PT. Remaja Rosdakarya, Bandung.

Moh. As'ad 2003 Psikologi industry = Seri Sumber Daya Manusia. Liberti. Yogyakarta. 
Nawawi, Hadari. 2006. Kepemimpinan Mengefektifkan Organisasi. UGM Gajah Mada University Press. Jogjakarta

Rivai, Veithzal, 2005. Performance Appraisal. Jakarta : PT. Raja Grafindo

Robbins.P.Stepen, 2006, Perilaku Organisasi, PTR Indeks Gramedia Group, Jakarta

Singgih Santoso. 2009. Panduan Lengkap Menguasai Statistik dengan SPSS. Jakarta: PT. Elex Media Komputindo.

Sugiyono. 2010. Metode Penelitian Bisnis.Bandung : Alfabeta

Suranta, Sri. 2002. Dampak Motivasi Karyawan Pada Hubungan Antara Gaya Kepemimpinan Dengan Kinerja Karyawan Perusahaan Bisnis. Empirika. Vol 15. Nomor 2

Tika H. Moh Pabendu. 2006. Budaya Oerganisasi dan Peningkatan Kinerja Perusahaan. PT Bumi Aksara. Jakarta

Toyib Armanu. 2005. Hubungan Kepemimpinan, Budaya, Strategi dan Kinerja : Pendekatan Konsep Fakultas Ekonomi Universitas Brawijaya. Malang.

Yasin Aziz, 2001, "Kepemimpinan dalam pengembangan Organisasi" Lintasan Ekonomi, Volume XVIII. No.1. Januari 2001 